\title{
Developing Innovative Business Models in Social Ventures
}

\author{
Päivi Jokela', Maria Elo²
}

\begin{abstract}
Social ventures represent a new type of organization that aim to create sustainable social value, such as promoting the well-being of communities and their existence is based on developing solutions to tackle complex social problems. Developing a suitable business model for a social venture is crucial because the right model with a sustainable value offering in its core can support the venture and direct it toward self-sustainability and competitiveness. Research on social venture business models has been so far limited and particularly innovation in business models needs more inquiry. Through an in-depth case study, we aim to extend the understanding how business models of social ventures can meet these goals and how the business model elements interact with each other. The study findings indicate that opportunity recognition which is followed by innovative resource mobilization and integration can turn into a well-functioning business-model that serves the desired ends, creating social value and help to achieve self-sustainability. Furthermore, establishing the right interconnections between the business model elements was found to support the development of an efficient social venture business model.

Keywords: social entrepreneurship, social ventures, business models, social value creation.
\end{abstract}

\section{INTRODUCTION}

The growing interest in working for the common good is manifested not only in corporate social responsibility initiatives, but also in the emergence of new organizations, social ventures specializing in running projects among less privileged groups of people and thus responding to social problems and injustices (Haynes, 2012; Felicio et al, 2013; Sud et al, 2009). Social entrepreneurship is thus driven by the need for social change, and social entrepreneurs act as change agents in adopting a mission to create and

\footnotetext{
1 Päivi Jokela, Postdoctoral researcher Dr, Turku School of Economics at the University of Turku, Department of Marketing, Fl-20014 Turun yliopisto, Finland, tel.: +358 2333 51, email: paivi.jokela@utu.fi.

2 Dr. Maria Elo, Turku School of Economics, University of Turku, Rehtorinpellonkatu 3, 20500 Turku, Finland, tel. +358 2 33351, e-mail: maria.elo@utu.fi.
} 
sustain social value instead of value measured in economic terms only (Choi \& Majumdar, 2013; Dees, 1998).

This evolving phenomenon has been acknowledged as a new type of entrepreneurship, drawing scholars to find a position for it in the entrepreneurship literature, which has traditionally focused on the wealth creating aspects of entrepreneurial activity (Haynes, 2012). The elevation of the social dimension has even been interpreted as a paradigm change and there is a growing body of literature that is focused on defining the phenomenon (Choi, 2013; Haynes, 2012; Short et al, 2009). The various definitions provide a multi-faceted description of what social entrepreneurship is, and how it has been approached. According to Oncer et al. (2010), social entrepreneurship is distinguished by the motivation and the purpose of the activity (Thake \& Zadek, 1997), with innovation in its core (Dees, 1998) together with accumulation of benefits and social value for various segments of the society (Austin et al, 2006; Zahra et al, 2009; Mair \& Marti, 2009). Particularly creation of social value has been a central point of interest in research on social entrepreneurship and it has been defined as both a preconditional purpose and an outcome of it (Mort et al. 2003; Thomson \& Doherty, 2006).

In spite of value creation's close connection to the development of efficient and competitive business models that are needed in order to achieve the desired ends (Alter, 2006) we still are lacking a systematic inquiry on how these models are developed and how they can best serve the mission of social ventures. While the abundancy of studies on business models of commercial ventures (see e.g. Chesbrough, 2007; Morris et al, 2005, Osterwalder, 2004) can contribute to understanding the models in social ventures to a certain extent, the special characteristics of the ventures require a more focused approach. Particularly the aspects of self-sustainability, competitiveness and innovation as part of the social venture goals set certain requirements and have to be considered in the development of business model for social ventures (Grassl, 2010). In these ventures business models can help to map the functions that are needed to maintain the activities. An important part of this process is to identify the funding stream and define how the income opportunities are created since in the new ventures the traditional donationbased strategies are often replaced with the income generating commercial projects. Business models can thus also help to outline the relationship between the business activities and social programmes and illustrate how social value and economic value are created (Alter, 2006).

Aimed at increasing the theoretical and practical knowledge of social ventures, this study explores and analyses a business model of a social venture that holds a portfolio of multiple social projects. The study addresses the key questions how the model is constructed in order to achieve self-sustainability 
by using innovation and how the model elements interact in the process supporting the model development. The methodology is qualitative and the inquiry was conducted by using case study strategy.

The paper is structured in a following manner: the second section introduces the concept of social venture and the elements of business model, presenting the theoretical framework for the study. The third section discusses the study methodology introducing briefly the case and the fourth section describes the case and the findings on its business model. The fifth section includes conclusions and discussion.

\section{THEORETICAL FRAMEWORK}

\section{Social ventures}

Social ventures can take many forms and there are numerous options how their activities are financed, what they offer and to whom. Social organizations can be run by volunteer resources or they can be funded by governments and private donations representing the traditional approach of non-profit organizations. They can include also for-profit firms with social offering ventures that focus on social outcomes as the main source of their profit, (e.g. health care services for the elderly replacing the public system) or any hybrid forms of these organizations (Felicio et al, 2013;) and as where the point of interest of this study is, organizations that look for innovative ways to finance their activities (Alter, 2006; Grassl, 2010). Social venturing can also be part of large corporations' social responsibility activities, with an appointed person or group taking the role of social entrepreneur within the organization.

While the pure commercial business ventures operating in the social space address markets that are often divided to certain customer segments, the concept of "markets" in social ventures is wider. It includes both the populations that participate in the social programmes offered by the venture, often with no cost, or the ventures can have a clientele base that pay for the social services or other services (Alter, 2006; Grassl, 2010). We discuss this further in the next section and propose that this division of markets impacts how the business model should be outlined.

Despite similarities between social and commercial ventures, it has been proposed that the key differentiating factor is the motivation of the key decision makers who get involved in the social activities, and the mission of the organization (Haynes, 2012). The distinction can be drawn between organisations where the purpose of the venture is to create social value, as opposed to private wealth (Austin et al., 2006). Social ventures can also be 
profit-oriented with the distinction that the wealth accumulated is injected back to the venture to provide means for the future projects (Grassl, 2010). It is also suggested that the focus may shift over time. In spite of an initial emphasis on the social ends, with increasing recognition or legitimacy, or both, the entrepreneurs may need to scale up their efforts and leverage their resources by adopting a more commercial approach (Austin et al., 2006).

In this study we use the narrow definition of social entrepreneurship, focusing on ventures that are founded to fulfil a social mission, based on an observed opportunity and innovation, with the aim of creating sustainable social value for the target audiences.

\section{Business models in social ventures}

The interest in business models has been growing as firms have realized that mapping their activities and understanding the relationships between the different business models elements. In the extant literature they commonly include value proposition or the offering, which can be a product or service or their combination, target markets, channels and networks that serve as an intermediate in the value offering delivery process, key resources that are needed internally and the financial element that explains the firm's revenue logic and cost structure (Osterwalder, 2004).

According to Grassl (2010) the business models of social ventures should fulfil the following conditions: to 1 ) be driven by a social mission and therefore the focus is not on distributing profit to shareholders 2) have a positive impact on society 3 ) recognize the centrality of the entrepreneurial function; and 4) support achieving competitiveness on markets through effective planning and management.

These conditions are further elaborated below from the perspective of developing a viable business model for social ventures.

Social ventures by definition should be attentive to the socially desired distribution of results and tie making profits to the social mission to support the cause of the venture (Grassl, 2010). Income earned and financial leveraging through business-oriented resource management enables practitioners to make new social project-related investments (Alter, 2006). Alter (2006) proposes further that this may be achieved the social projects and commercial activities can be integrated by commercializing social services to new fee-paying markets or by providing new services to existing clients. This is characterized as "integrated" social ventures, the target groups benefiting from investments made in social programmes through the earned income, irrespective to their involvement in the venture's operations (Alter, 2006). For this reason also the business model elements can firstly be studied at target 
population level, identifying the beneficiaries, their needs and the means of the venture to meet those needs. Secondly, social ventures can develop models for the customers that by accepting the value offering participate as value co-creators in the venture activities.

Social value creation forms the primary objective and precondition for social venture establishment (Choi \& Majumdar, 2013; Mair \& Martí, 2006) and it refers to the production of such offerings and their outcomes that advance justice, fairness and welfare in a given human community (Austin et al., 2006; Peredo, 2006). The value created can take tangible or intangible forms, expressed often in terms of social inclusion of less privileged groups through the following concepts: well-being, social responsibility, social recognition, proximity, human development, involvement and engagement (Felício et al., 2013; Omidvar \& Richmond, 2003). According to Omidvar and Richmond (2003) the overall aim of social inclusion is to close the physical, social and economic distances separating people, rather than only to remove the barriers existing between different groups.

Ventures thus often aim to achieve a wider society-related impact, which can be mediated by the target group, or, depending on the focus of the venture, the primary target group can be the society as a whole, for example, software that is developed by volunteers to benefit citizens by providing information concerning society-related decisions (http://www.hasadna.org. il/en/our-projects/open-knesset/). Although measuring social impact and value is challenging, and only in certain cases the results can be measured, for example, in the development of skills, reduced use of energy, etc., this is not the even the primary objective in all social ventures (Austin et al., 2006).

Key processes in the social ventures like in any enterprise are the opportunity recognition and assembly of resources: people, relationships and skills in a novel way. According to Felício et al. (2013), the entrepreneurial orientation of the venture managers has a positive effect on the creation of social value. Social innovations imply creating novel approaches for tackling social issues, and they form an essential element in social entrepreneurship (Choi \& Majumdar, 2013). Organizations with higher initiative and more innovation contribute to the achievement of greater value (Felício et al., (2013). 


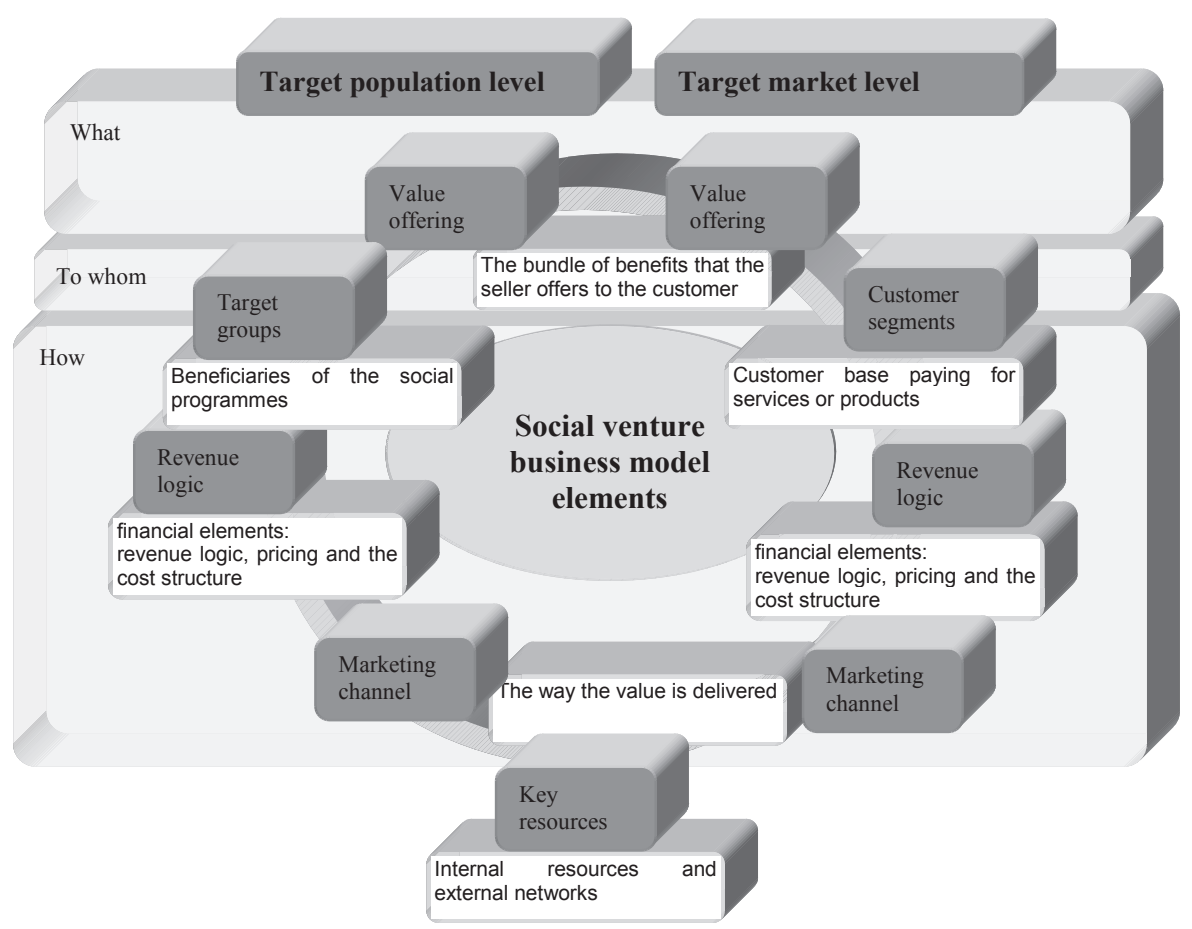

Figure 1 Zeze business model elements

Source: The authors, modified based on Osterwalder (2004).

Also other business model elements that are presented in Figure 1 can be examined separately following the proposed division. Depending on the nature of the social venture some of the elements may not have significance (e.g. revenue model at the target population level as the beneficiaries may not pay for the services they receive and could be replaced with "value creation logic") or their contents can be different than in commercial organizations. This concerns especially the key resources. While corporations running social programs benefit from the specialized skills and capabilities that they have in their business management (Hess et al., 2002), social ventures can rarely claim the same. Although social ventures could have much flexibility in terms of planning and testing models with novel elements, it does not change the fact that there has to be a match between the purpose of the venture and its resources. Configuration of these two can be continuously evolving because the economic, sociocultural and political context, and also the available resources can be expected to change, requiring realignment and the awareness of the entrepreneur (Austin et al., 2006). The result should be 
a competitive and sustainable model that supports the venture activities and continuous venture development.

\section{Methodology}

This qualitative study, constructed as a case study (Yin, 1984), follows an explorative and descriptive strategy, attempting to widen understanding of the complex, real-life concept of social entrepreneurship. Both primary and secondary data were collected from multiple sources (Alasuutari, 1995) and these were analysed and compared to provide an in-depth picture of business models in the context of social entrepreneurship (Helkama, Myllyniemi \& Liebkind, 2010; Stake, 2005). The focal case study was purposefully selected to match the criteria describing social venture including the idea of striving for competitiveness and fostering innovation in their activities which also was reflected in its business model (Choi \& Majumdar, 2013; Grassl, 2010). The Tel Aviv-based social venture Zeze was established in 2010 as a continuation of activities of two brothers who recognized a need for providing interesting activities for the elderly. Zeze is dedicated to carrying out social projects with the aim of making a sustainable social impact. The venture is based on a platform that provides a basis for different types of social projects, run mainly by young volunteers. It looks for projects with creative elements, and thus offers an innovative way of getting young people involved. In Zeze, the management of the projects takes place through different layers. The core team consists of the founders and the CEO of the venture, and beyond that there are 40 more permanent volunteers and other volunteers, with the number involved in their projects already up to one thousand.

The primary data was collected in Israel in 2011-2014 by interviewing the key informants the social entrepreneurs in three different occasions. Short follow-up questions and verifications were asked also of the family members of the entrepreneurs, because of their role in supporting the venture development with their business experience and thus contributing to the formation of the venture. The secondary data includes video clips about the activities of the venture, interviews with the founders and key managers, newspaper articles and materials published by the company on their website. A longitudinal approach was adopted in data collection, as the social venture and its development were followed for three years. The case analysis was guided by the concepts of the theoretical framework, the business model elements and the criteria proposed for the models. Aligned with the tradition of interpretative sense-making, the findings indicate implications that are idiographic and seek to understand the particular rather than to generate law-like explanations (Welch et al., 2011). On the other hand, considering 
the contextual factors, the results can to a certain extent be transferable. The value of the case study lies in the rich description and the possibility to contribute to understanding better the logic of the social ventures, the innovation in the development of their business model and achieving selfsustainability.

\section{CASE DESCRIPTION OF - ZEZE SOCIAL PROJECTS BUSINESS MODEL}

\section{Background}

When a young Israeli man, on completing his national service in an elderly day-care centre, shared with his friend Daniel his concern that there was a lack of interesting activities for the elderly, or the funding required for them, they felt that they could do something about it. However, they also decided that the conventional approach of asking for donations would be very boring, and they would try to think of funding the activities in some other way. They came up with an idea of organizing parties for young people that would create the needed revenue for the day-care centre activities. The founders also reasoned that for the young volunteers that they intended to recruit the typical NGO's with their hierarchical structures, bureaucracy, and the traditional ways of helping people would not necessarily be appealing. Their expectation was that this alternative would make a difference as the participation in the activities should be fun, and that the volunteers should be able to use their talents. This was indeed the case as a great number of young volunteers offered their skills and time to promote the events and take care of the arrangements for the parties, which turned out to be successful.

The income from the parties was used to maintain and develop various new projects with an aim of creating social value in its different forms for the target groups. The participation of the volunteers and the value creation for them was emphasized as well. The idea of Zeze was crystallized by one of the founders in the following way: "These are the criteria for how we do projects: the projects have to be creative and they have to have a social aim of course. They also have to empower both sides, both the volunteer and also the social target."

Besides the creating activities for the elderly, there was a project called Zotzot that helped former female prisoners by teaching them graphical design skills, with the purpose of preparing items for sale, and ultimately assisting women in rehabilitation to find their way back into normal life. Another successful project took place by setting up a special orchestra, the Streets Philharmonics. This project targeted immigrants who are talented musicians, mainly from the former USSR, and who found it difficult to penetrate Israel's 
small music industry. The Zeze founders approached these musicians on the streets where they were playing, and proposed that they could join the orchestra. The performances were a huge success, with audiences of up to a thousand at a concert, and firms and government institutions commissioned the orchestra to play at their events. The musicians were paid from the concert revenues according to the standards of the music industry. In the past, Zeze also managed a project that organized summer camps for children from lower socio-economic neighbourhoods in Tel Aviv. For this project, Zeze provided opportunities for older school kids to participate as counsellors, to receive experience and a proper salary. These counsellors represented minorities from rough neighbourhoods: Arabs, African refugees and Ethiopians.

In addition to the volunteers and few staff with salary, there have been students who got involved through collaboration between Zeze and Tel Aviv University, and the Shenkar College of Engineering and Design. Through these academic organisations scholarships were made available for participants. One of the founders described the method in the following statement: "The project's participants receive mentoring, funds and the connections needed from the community, in order to bring unique social projects to life."

\section{THE BUSINESS MODEL OF ZEZE SOCIAL VENTURE - FINDINGS}

\section{The social venture model criteria at Zeze}

Zeze's business model fit to the criteria set for social venture model by Grassl (2010), including the focus on and drive by social mission, creation positive spillovers impacting the society, recognizing the centrality of the entrepreneurs and entrepreneurial process; and achieving competitiveness on markets through effective planning and management.

It was obvious that Zeze was to a great extent focused on their social mission. It succeeded in combining social ends with revenue generation while benefitting the customers, volunteers and other stakeholders, thereby providing intelligently planned means to maintain their social activities. The social impact achieved by the venture was multifaceted. The venture fulfilled the original purpose of creating sustainable social impact in the target audience by creating feelings of integration, support as a result of group activity, and satisfaction from the participation, but in addition, there were other, unplanned positive impacts that occurred: the volunteers benefited from involvement as their skills and experience accumulated in the areas of their expertise. One example was a young man who developed the promos for the events and was subsequently able to use the works as references when opening his own business. Also a junior graphic designer was given the 
opportunity to design a one-page advertisement for a prominent newspaper. Building such a wide portfolio and winning a place in a country-wide newspaper would have hardly been possible for these young professionals without their involvement with Zeze.

Value created in the form of inclusion, or by providing benefits for less privileged groups, such as school children, the elderly or immigrants, was the main focus of Zeze. For the musicians their inclusion provided an employment opportunity, an income and a stage to use their talents on a more appreciated platform and as a part of an orchestra rather than just playing alone on the street, although Zeze does also recognise street music as a significant form of the arts. However, from the musicians' point of view, the importance of receiving a salary was sometimes of lesser importance than their increased confidence derived from playing on the stage for a large audience. Importantly, commercial firms formed a significant customer base for the Streets Philharmonics. The various backgrounds of the musicians added value to the orchestra, as reference to the world music they represented was used in marketing the concerts. Teaching graphic design to former prisoners contributed to their inclusion, as the project encouraged them both through learning new skills and through the results of their work. In the school children project, according to the founder, it was empowering for the counsellors to see that they could be a "part of the solution for others" and not only to be considered as those whose problems needed to be solved.

The entrepreneurs and the opportunity recognition process were central for developing the venture and their motivation was to make a change. This also applied to the managers who were hired for the projects when the activities matured and there was a need for a more professional management. The salaries offered were lower than in the business sector implying that the key people had to be motivated by the cause of the project. However, according to the founders, this should not necessarily be the case. They believe that a social venture should find a model that is fully self-sustainable and comparable to commercial ventures, at least in terms of hiring key managers.

The competitiveness criterion was already met to great extent with the current model of Zeze. Creating revenue from certain social projects and investing the income in other projects turned out to be a successful way of financing the activities. The skills and knowledge base of the volunteers formed the basis for carrying out the projects and it was assessed the young people were doing a very good job. 


\section{Zeze's business model}

The Zeze's business model was in accordance with the two-level model of social ventures introduced in the section 2.2. Firstly, there were various target populations who participated in the projects, from the musicians to children in need. Secondly, there were different customer segments that participated in value creation by generating revenues for the projects, including young people who came to the parties and various concert audiences. An important group within the latter were companies that could, in this way, demonstrate social responsibility to their own stakeholders. When events were offered to the wider public, the venture itself benefited from this, because awareness often turned into people's willingness to get involved. The value offering for the target population included various activities aiming at their inclusion, but for the customer segments the venture developed different marketable products, e.g. the parties, the plates designed by the women, or the concerts.

The channel element as focused on marketing and it was largely based on the use of Internet and word of mouth on both target market levels. The use of social media in marketing Zeze activities and locating suitable volunteers was essential, but the events spread the word about these activities, providing thereby not only a marketing channel for new customers, but also for new volunteers.

Besides the volunteers, the people that targeted with the projected formed also a key resource for the same projects in the case of concerts and children camps. The revenue logic was that the ticket sales invested back to support the activities and for the target populations' participation in projects was of no cost but on the contrary, in some cases it also created income for them. Figure 2 above illustrates the Zeze business model and it has been modified to correspond to the social venture model.

\section{DISCUSSION AND CONCLUSIONS}

The study enriches the extant theoretical views on social ventures and social entrepreneurship by contributing to the understanding of social venture business models and the linkages between the model elements. The case study on Zeze projects reveals how innovation in the business model elements and in their interrelations can impact the venture self-sustainability and help locating the required resources for maintaining the venture activities and achieving the desired social ends. Our findings show that underprivileged groups including immigrants, children from low-socio-economic backgrounds, the elderly and former prisoners, still are the main target audience benefitting from social inclusion in its various forms (Austin et al., 2006; Sud et al., 2009). The tangible and intangible elements of social inclusion, material well- 
being, recognition and involvement were ways of value creation (Omidvar \& Richmond, 2003). However, the value was observed to flow in the venture bidirectionally: toward the pre-defined target audiences but also toward the other participating groups, including business organizations that were active parties in roles other than that of a donor.

Based on the analysis of the results, the earlier definitions of social ventures and the criteria set for their business models that emphasized the role of the social entrepreneur as a driving force, the overall social impact through value creation, innovativeness in the venture activities and competitiveness (Austin et al., 2006; Choi \& Majumdar, 2013; Felicio et al., 2013; Grassl, 2010; Mair \& Martí, 2006) were clearly manifested in the Zeze projects. This opens new avenues for understanding the venture models via the studied case.

The model elements from the two different levels, target population and target market level, were interrelated in several ways. The earlier suggestion of Alter (2006), according to which it is difficult to employ the target groups in projects or that the employment may not contribute to the venture's competitiveness in a desired manner was contradicted in this study. Several different target groups were involved in the venture projects served as key resources either provided their time in the voluntary projects to help for others or brought their skills to bring finances for the other projects in the portfolio, like the musicians did. In the case of Zeze, the innovativeness lies in the processes of resource integration and mobilization, and in the venture model itself, more than in its outcomes. A key to the competitiveness and sustainability was thus on the one hand in the innovative nature of fundraising and locating the right volunteers to serve as resources for it as well as in the diversification of the projects that supported one another. In other words the model was designed in such a way that it supported the construction of a network of people, its key resource and an essential element in maintaining the activities. In the model development the entrepreneurs emphasized innovation and using great creativity in their planning the model. An important driving force here was their own social setting and demographical factors: From this perspective the young entrepreneurs recognized the opportunities and acted upon seizing them accordingly.

Creating marketable products and services for an expanding customer base placed Zeze into the category of hybrid ventures that combining social activities with commercial ends (Grassl, 2012). The marketable idea that was turned into a successful value offering was a key to revenues which were invested back into the venture allowing development of existing projects and the launching of new ones from the same platform. This is contrary to the traditional approach to social organizations that highlights donations or 
governmental support (Felicio et al., 2013). The commercial aspect assures independence for the venture and allows greater flexibility in relation to the contents of the projects and their target audiences. For the customers, including the corporate or other institutional actors who buy concerts and concert tickets, involvement in the venture reflects their socially responsible activities and manifests through an enhanced corporate reputation as perceived by their stakeholders. Through the creativity exercised in planning the activities, the venture has been able to reach out to a great number of young people and lead them to get engaged by allowing them to follow their passion in doing things that they would be doing otherwise anyway. For the volunteers, the development of skills was significant within the framework of the venture when they participated in creating the value offerings.

The limitations of the study relate to the size of the studied population. The future aim is to include more and varying yet comparable cases to assess the aspects of this study in different settings. This would enrich the learning from models of different organizations and their way of handling innovation and self-sustainability related issues that form the imminent challenge for social ventures.

\section{References}

Alasuutari, P. (1993). Laadullinen tutkimus, Vastapaino: Tampere.

Alter, S. (2006). Social enterprise models, their mission and money relationships. In: A. Nicholls, (Ed.) Social entrepreneurship: new models of sustainable social change, 205-232, University Press: New York.

Austin, J., Stevenson, H. and Wei-Skillern, J. (2006). Social and Commercial Entrepreneurship: Same, Different, or Both? Entrepreneurship Theory and Practice, 30(1), 1-22.

Chesbrough, H. (2007). Business Model Innovation: It's Not Just About Technology Anymore. Strategy \& Leadership, 35(6), 12-17.

Choi, N. and Majumdar, S. (2014). Social Entrepreneurship as an Essentially Contested Concept: Opening New Avenue for Systematic Future Research, Journal of Business Venturing, 29(3), 363-376.

Dees, G. (1998). The meaning of "social entrepreneurship. Draft Report for the Kauffman Center for Entrepreneurial Leadership: Stanford University.

Felício, J., Gonçalves H. M. and Gonçalves, V. da C. (2013). Social Value and Organizational Performance in Non-profit Social Organizations: Social Entrepreneurship, Leadership, and Socioeconomic Context Effects. Journal of Business Research, 66(10), 2139-2146.

Grassl, W. (2012). Business Models of Social Enterprise: A Design Approach to Hybridity, ACRN Journal of Social Entrepreneurship Perspectives, 1(1), 37-60. 
Haynes, P. (2012). The Social of Social Entrepreneurship: Building a New Field Using a New Paradigm, American Journal of Entrepreneurship, 5(1), 5769.

Hess, D., Rogovsky, N. and Dunfee, T. W. (2002). The Next Wave of Corporate Community Involvement: Corporate Social Initiatives. California Management Review, 44(2), 110-125.

Mair, J. and Marti. I. (2006). Social Entrepreneurship Research: A Source of Explanation, Prediction, and Delight. Journal of World Business, 41(1), 36-44.

Morris, M., Schindehutte, M. and Allen, J. (2005). The Entrepreneur's Business Model: Toward a Unified Perspective. Journal of Business Research, 58(6), 726-735.

Mort, G.S., Weerawardena, J. and Carnegie, K. (2003) . Social Entrepreneurship: Towards Conceptualisation, International Journal of Nonprofit and Voluntary Sector Marketing, 8(1), 76-88.

Omidvar, R. \& Richmond, T. (2003). Immigrant Settlement and Social Inclusion in Canada. (Working Paper Series Perspectives on Social Inclusion: Laidlaw Foundation). Retrieved from http://library.bsl.org.au/jspui/ bitstream/1/626/1/Immigrant_Settlement_and_Social_Inclusion_in_ Canada.pdf.

Oncer, A. Z. and Yildiz, M. L. (2010). Creating Sustainable Value for Society: Social Entrepreneurship. The Business Review, Cambridge, 14(2), 222 228.

Open Knesset-project. Retrieved from http://www.hasadna.org.il/en/ourprojects/open-knesset/.

Osterwalder, A. (2004). The Business ModelOntology-AProposition In a Design Science Approach, (PhD dissertation, University of Lausanne). Retrieved from http://www.hec.unil.ch/aosterwa/PhD/Osterwalder_PhD_ BM_Ontology.pdf.

Peredo, A. and McLean, M. (2006). Social Entrepreneurship: A Critical Review of the Concept. Journal of World Business. 41(1), 56-65.

Short, J.C., Moss, T.W. and Lumpkin, G.T. (2009). Research in Social Entrepreneurship: Past Contributions and Future Opportunities. Strategic Entrepreneurship Journal, 3(2), 161-194.

Sud, M., VanSandt, C.V., Baugous, A. M. (2009). Social Entrepreneurship: The Role of Institutions. Journal of Business Ethics, 85(1), 201-216.

Thake, S. and Zadek, S. (1997). Practical People, Noble Causes: How to Support Community Based Social Entrepreneurs, New Economic Foundation.

Zahra, S. A., Gedajlovic, E., Neubaum, D. O. and Shulman, J. M. (2009). A Typology of Social Entrepreneurs: Motives, Search Processes and Ethical Challenges. Journal of Business Venturing, 24(5), 519-532.

Welch, C., Piekkari, R., Plakoyiannaki, E. and Paavilainen-Mäntymäki, E. (2011). Theorising from Case Studies: Towards a Pluralist Future for International Business Research, Journal of International Business Studies. 42(5), 740-762. 
Yin, R. (1989). Case study research: design and method. Sage Publications: New York.

\begin{abstract}
Abstrakt (in Polish)
Przedsięwzięcia społeczne reprezentujq nowy typ organizacji, których celem jest stworzenie trwałej wartości społecznej, takiej jak promowanie dobrobytu społeczności, a ich istnienie opiera się na tworzeniu rozwiqzań do radzenia sobie ze złożonymi problemami społecznymi. Opracowanie odpowiedniego modelu biznesowego przedsięwzięcia społecznego jest kluczowe, ponieważ odpowiedni model o zrównoważonej ofercie wartości może wspierać przedsięwzięcie i skierować je w kierunku samowystarczalności i konkurencyjności. Badania na modelach przedsięwzięć społecznych jak dotad sq ograniczone, tak więc w szczególności innowacje w modelach biznesowych wymagajq większego zainteresowania. Poprzez pogłębione badanie przypadku staramy się rozszerzyć wiedzę, jak modele biznesowe przedsięwzięć społecznych mogq osiqgnqć swój cel, oraz w jaki sposób elementy modelu biznesowego współdziałajq ze sobq. Wyniki badania wskazujq, że rozpoznanie możliwości, po których następuje mobilizacja i integracja innowacyjnych zasobów, może przekształcić się $w$ dobrze funkcjonujqcy biznes-model, który służy do pożqdanych celów, tworzenia wartości społecznej i przyczynić się do osiqgnięcia samowystarczalności. Ponadto, ustalenia właściwych wzajemnych powiqzań pomiędzy elementami modelu biznesowego okazały się wspierać rozwój efektywnego modelu biznesowego przedsięwzięcia społecznego. Słowa kluczowe: przedsiębiorczość społeczna, przedsięwzięcia społeczne, modele biznesowe, tworzenie wartości społecznej.
\end{abstract}

\title{
Biographical notes
}

Dr. Päivi Jokela is a post-doctoral researcher at Turku School of Economics at the University of Turku, Finland. She acquired her PhD in Business Administration at Turku School of Economics, Finland as part of the Valuenetresearch group. Päivi Jokela's current research focuses on sustainability issues in business relationships, social responsibility in entrepreneurship, business models, diaspora networks and firm internationalization. Her research has been published in numerous conference proceedings, in book and journals such as Management International Review and International Journal of Technology Marketing.

Dr. Maria Elo is a post-doctoral researcher at Turku School of Economics at the University of Turku, Finland and a Migration Fellow at the Institute of Migration in Finland. She acquired her PhD in Economics at Åbo Akademi University, Finland as part of the Valuenet-research group. She is the founder and leader of the Diaspora Networks in International Business- research platform and the treasurer of The Society for the Study of Ethnic Relations and International Migration (ETMU). Her current research focuses on international business, diaspora networks and resources, emerging markets, 
and non-prime business. Her work is presented in numerous conferences and workshops, and published in books and journals, such as Industrial Marketing Management and Int. J. Manufacturing Technology and Management. 